ROCZNIKI NAUK PRAWNYCH

Tom XXIX, numer $1-2019$

DOI: http://dx.doi.org/10.18290/rnp.2019.29.1-4

PIOTR K. SOWIŃSKI

\title{
JESZCZE O TAJEMNICY ADWOKACKIEJ \\ Z PERSPEKTYWY PRZEPISÓW ART. 178 PKT 1 ORAZ 180 § 2 K.P.K. UWAGI POLEMICZNE
}

\section{WPROWADZENIE}

Uważna lektura testu autorstwa mgr P. Krzyżanowskiego opublikowanego w numerze t. XXVIII (2018), nr 3 „Roczników Nauk Prawnych” (s. 33-50) skłoniła mnie do napisania tych kilku niewątpliwie krytycznych uwag, mających na celu sprostowanie dostrzeżonych tam nieścisłości oraz uzupełnienie szeregu luk, bez czego obraz tajemnicy adwokackiej w postępowaniu karnym byłby niepełny. Nie ulega wątpliwości, że tajemnica ta stanowi niezwykle ważny element wykonywania zawodu przez adwokata, zaś jej zachowanie - w granicach prawa - jest obowiązkiem każdego palestranta (adwokata i aplikanta adwokackiego). Choć jest to instytucja towarzysząca adwokaturze niemal od zarania, to zarazem poufność nie jest cechą przypisaną wyłącznie temu tylko środowisku zawodowemu. Poufność informacji cechuje także przedstawicieli innych zawodów, z których kilka wymienia ,imiennie” wielokrotnie już nowelizowany po 1997 r. przepis art. 180 § 2 k.p.k. ${ }^{1}$ Okoliczności tej P. Krzyżanowski w ogóle nie dostrzega, choć wskazanie to jest ważne dla zrozumienia otoczenia prawnego i porzucenia tezy o rzekomej wyjątkowości tajemnicy adwokackiej. Opuszczenia tego nic nie usprawiedliwia, przy czym szczególnie razi pominięcie kwestii tajemnicy zawodowej radcy prawnego. A przecież podobnie, jak ma się to w przypadku adwokata, jest to również zawód polegający na udzielaniu ,pomocy prawnej [...] w celu ochrony prawnej interesów podmiotów, na których rzecz jest [ona - P.K.S.] wykonywana"

Dr hab. PIOTR K. SowiŃSKI, prof. UR - Kierownik Zakładu Prawa Karnego Procesowego, Wydział Prawa i Administracji Uniwersytetu Rzeszowskiego, ul. Grunwaldzka 13, 35-068 Rzeszów; https://orcid.org/0000-0003-2210-5877

${ }^{1}$ Ustawa z dnia 6 czerwca 1997 r. Kodeks postępowania karnego, Dz. U. z 2018 r., poz. 1987 z późn. zm. [dalej cyt.: k.p.k.]. 
i z tego powodu zasługiwał on na małą choćby wzmiankę. Już tylko pobieżna analiza rozwiązań zawartych w art. 1 ust. 1 (pomoc prawna), art. 3 ust. 2 (etyka zawodowa), art. 5 ust. 1 (samorząd zawodowy) ustawy z dnia 6 lipca 1982 r. o radcach prawnych ${ }^{2}$ wskazuje, że są to rozwiązania wręcz bliźniaczo podobne do tych, które przewiduje art. 4 ust. 1 (pomoc prawna), art. 3 ust. 1 pkt 5 (etyka zawodowa) i art. 1 ust. 2 ustawy z dnia 26 maja 1982 r. - Prawo o adwokaturze (samorząd zawodowy) $)^{3}$. Identyczne są wreszcie rozwiązania dotyczące kwestii zachowania w tajemnicy ,wszystkiego, o czym dowiedział się [dany profesjonalista - P.K.S.] w związku z udzielaniem pomocy prawnej" (por. art. 3 ust. 3 u.r.pr. oraz art. 6 ust. 1 Pr.adw.).

Zamieszczony przez P. Krzyżanowskiego wykaz pozycji bibliograficznych, poza może dwoma - trzema wyjątkami, to pozycje wydane głównie po 2005 r., podczas gdy najgorętszy spór o kształt tajemnicy adwokackiej przetoczył się przez polskie środowisko naukowe w okresie poprzedzającym uchwalenie dwóch powojennych kodeksów postępowania karnego, tj. z 1969 i 1997 r. Dorobek doktryny z tego okresu jest niemal zupełnie niewidoczny w rozważaniach Autora, tak jakby uległ on swoistego rodzaju ,przedawnieniu”. Jest to zresztą przypadłość cechująca wielu początkujących Autorów, nad czym zresztą szczerze ubolewam. Nie da się napisać satysfakcjonującego tekstu prawniczego, bez zapoznania z głosami takich przedstawicieli nauki i praktyki, jak chociażby prof. M. Cieślak ${ }^{4}$, prof. A. Gaberle ${ }^{5}$ czy wreszcie prof. E. Skrętowicz ${ }^{6}$. W obiegu bibliotecznym dostępne są trzy monografie traktujące szczegółowo o tajemnicy adwokackiej z perspektywy karnoprocesowej. Są to pozycje: K. Łojewskiego z $1970^{7}$, moja z $2004^{8}$ oraz P. Rusinka z 2007 r., przy czym P. Krzyżanowski sięga wyłącznie po tę ostatnią. Zupełnie przemilczana został praca prof. B. Kunickiej-Michalskiej o ochronie tajemnicy, choć ma ona zupełnie zasadnicze znaczenie dla zrozumie-

\footnotetext{
${ }^{2}$ Ustawa z dnia 6 lipca 1982 r. o radcach prawnych, Dz. U. z 2017 r., poz. 1870 z późn. zm. [dalej cyt.: u.r.pr.].

${ }^{3}$ Ustawa z dnia 26 maja 1982 r. Prawo o adwokaturze, Dz. U. z 2018 r., poz. 1184 z późn. zm. [dalej cyt.: Pr.adw.].

${ }^{4}$ M. CIEŚLAK, Tajemnica adwokacka w procesie karnym. Glosa do wyroku SN z 12 listopada 1964 r. (II KK 1018/61), „Państwo i Prawo” 3 (1966), s. 591.

${ }^{5}$ A. GABERLE, Glosa do uchwaty siedmiu sędziów SN z 16 czerwca 1994 r., I KZP 5/94 (ochrona tajemnicy adwokackiej w świetle art. 1963 k.p.k.), „Państwo i Prawo” 4 (1995), s. 108 n.

${ }^{6}$ E. SKRĘTOwicz, E. KRUK, O tajemnicy adwokackiej w procesie karnym, „Annales UMCS” 43 (1996), s. 130 n.

${ }^{7}$ K. ŁOJEWSKI, Instytucja odmowy zeznań w polskim procesie karnym, Warszawa: Wydawnictwo Prawnicze 1970, s. 151-186.

${ }^{8}$ P.K. SowiŃski, Prawo świadka do odmowy zeznań w procesie karnym, Warszawa: Wydawnictwo C.H. Beck 2004, s. 166-183.
} 
nia istoty tajemnicy zawodowej jako instytucji prawa pozytywnego ${ }^{9}$. Kończąc ten wątek zwracam wreszcie uwagę na zupełną absencję w bibliografii dorobku prof. Z. Kwiatkowskiego ${ }^{10}$, choć akurat głos tego właśnie Autora winien być uwzględniony w tej części opracowania, gdzie mówi się o tajemnicy adwokackiej w kontekście zakazu dowodowego.

\section{UJĘCIE TAJEMNICY ZAWODOWEJ ADWOKATA W PRZEPISACH USTROJOWYCH ADWOKATURY ORAZ W PRZEPISACH K.P.K. Z 1997 R.}

Przed przystąpieniem do analizy granic „tajemnicy adwokackiej”, warto odnotować, że termin ten nie występuje ani w Prawie o adwokaturze, ani w żadnym z wcześniejszych aktów normatywnych regulujących ustrój odrodzonej adwokatury polskiej. Mowa jest tam jednak o obowiązku zachowania „tajemnicy”, oraz o składowych objętych nakazem poufności. Termin „tajemnica adwokacka”, aczkolwiek początkowo bez normatywnego umocowania, rozpowszechnił się jednak w doktrynie prawa karnego procesowego i judykaturze jako wyraz pewnej konwencji językowej. Od 1997 r. jest też obecny w treści art. 180 § 2 k.p.k., który go jednak nie rozwija. W omawianym tu tekście założono konieczność porównania zakresu przedmiotowego tajemnicy adwokackiej w przepisach ustrojowych adwokatury oraz karnoprocesowych (s. 34), choć te ostatnie problematyką tą $\mathrm{n}$ i e $\mathrm{m}$ a 1 się nie zajmują. Wspomniany art. 180 § 2 k.p.k. wymienia wprawdzie „tajemnicę adwokacką”, jednak ogranicza się on do wskazania sposobu zachowania się przez jej depozytariusza w sytuacji konfliktowej (przesłuchanie co do okoliczności poufnych - a contrario art. $180 \S 2$ zd. 1 k.p.k.) oraz warunków rozwiązania tego konfliktu (zwolnienie z obowiązku zachowania tajemnicy - art. 180 $\S 2$ zd. 2 i następne k.p.k.). Przepis ten nie redefiniuje więc „tajemnicy adwokackiej" na potrzeby karnoprocesowe.

Sygnalizowanym wcześniej wyjątkiem (,niemal”) jest rozróżnienie dokonane w oparciu o art. $180 \S 2$ i art. 178 pkt 1 k.p.k. na tajemnicę adwokacką i tajemnicę obrończą, o czym będzie jeszcze dalej mowa. Poza tym jednym, aczkolwiek istotnym wskazaniem, ustawa karnoprocesowa nie zawiera przepisu, który mógłby stanowić podstawę do odrębnego traktowania zakresu tajemnicy adwokackiej

\footnotetext{
${ }^{9}$ B. KUNICKA-MiChALSKA, Ochrona tajemnicy zawodowej $w$ polskim prawie karnym, Warszawa: Wydawnictwo Prawnicze 1972, s. 116 n.

${ }^{10}$ Z. KWIATKOWSKI, Zakazy dowodowe $w$ procesie karnym, Katowice: Wydawnictwo UŚ 2001, s. 148 n. oraz tegoż Autora, Zakazy dowodowe w procesie karnym, Kraków: Zakamycze 2005, s. 196 n.
} 
z perspektywy procesowej. Skoro tak, to i w warunkach procesu karnego przedmiotem tajemnicy adwokackiej jest „wszystko, o czym dowiedział się [on P.K.S.] w związku z udzielaniem pomocy prawnej" (art. 6 ust. 1 Pr.adw.), niezależnie od rodzaju tej pomocy (art. 4 ust. 1 Pr.adw.), podmiotu korzystającego z tej pomocy (art. 4 ust. 2 Pr.adw.), formy wykonywania zawodu (art. 4a Pr.adw.), a wreszcie źródła, z którego uzyskał chronioną informację czy czasu jej uzyskania (art. 6 ust. 2 Pr.adw.). W realiach procesowych równie chronione będą informacje natury cywilnoprawnej, jak i karnoprawnej, dotyczące życia prywatnego klienta, jak i jego aktywności zawodowej. Tajemnica chroni informacje pochodzące od klienta, jak i osób trzecich, byleby tylko wykazywały one związek z wykonywanym przez adwokata zawodem. Brak wskazania zakresu przedmiotowego tajemnicy adwokackiej w przepisach kodeksowych nie jest żadną przeszkodą, aby in concreto ustalić, co składa się na tę tajemnicę. W tym celu wystarczy odwołać się do odnośnych rozwiązań korporacyjnych. Zupełnie chybiona i nieprzekonująca jest więc konstatacja, jakoby na użytek procesu karnego zakres ten należało zdefiniować na nowo (s. 47), gdyż prowadziłoby to do zbędnej multiplikacji pojęć. Podejmując się tego zadania ustawodawca, idąc niejako „za ciosem”, musiałby bowiem podobnie potraktować i inne tajemnice zawodowe wymienione $\mathrm{w}$ art. 180 § 2 k.p.k., gdyż tylko w ten sposób zdołałby uniknąć zarzutu preferowania jednej z nich.

$\mathrm{Z}$ tezą co do niedookreślenia zakresu tajemnicy adwokackiej na gruncie karnoprocesowym zgadza się E. Kruk ${ }^{11}$, zaś odnośnie do podobnie skonstruowanej tajemnicy notarialnej także K.J. Pawelec ${ }^{12}$ oraz Cz.P. Kłak ${ }^{13}$. Wszyscy ci Autorzy uważają jednak takie podejście za optymalne z uwagi na obecność w polskim systemie prawa aktów normatywnych szczegółowo regulujących zasady działania poszczególnych korporacji. Niestworzenie odrębnej ,procesowej” definicji tajemnicy zawodowej (tj. adwokackiej i innych wymienionych w art. 180 § 2 k.p.k.) podyktowane jest chęcią stworzenia takiego mechanizmu ochrony tajemnicy zawodowej oraz takiego trybu jej uchylenia, które przez swą uniwersalność byłyby w stanie objąć szerszą grupę zawodów, których istota wymaga utajnienia wiadomości posiadanych przez osoby praktykujące w tych zawodach. Wydaje się, że naszemu ustawodawcy udało się takie właśnie rozwiązania wypracować, choć

\footnotetext{
${ }^{11}$ E. KRUK, Obowiązek zachowania tajemnicy adwokackiej jako okoliczność uzasadniająca odmowe zeznań w trybie art. 180 § 1 k.p.k., „Studia Iuridica Lublinensia” 4 (2017), s. 28.

${ }^{12}$ K.J. PAweleC, Tajemnica zawodowa notariusza $w$ znowelizowanym Kodeksie postępowania karnego. Zagadnienia podstawowe, „Rejent” 9 (2015), s. 96.

${ }^{13}$ Cz.P. KŁAK, Ochrona tajemnicy notarialnej w polskim procesie karnym, „Prokuratura i Prawo" 1 (2013), s. 33.
} 
zainteresowane nimi grupy zawodowe wcale nie są skłonne uznać ich legalności. To, iż problematyka tu omawiana jest nadal aktualna widać na przykładzie reakcji społecznych na ostatnią inicjatywę Ministerstwa Sprawiedliwości nowelizacji art. $180 \S 2$ k.p.k. ${ }^{14} \mathrm{Na}$ tajemnicę adwokacką nie składa się sam fakt udzielenia (,świadczenia”) pomocy prawnej, choć próby objęcia takiego faktu tajemnicą były podejmowane w obrębie ,siostrzanej” korporacji radców prawnych, o czym wspomina w literaturze przedmiotu A. Machnikowska ${ }^{15}$. Wydaje się zresztą, że rozszerzenie tajemnicy w tym kierunku, byłoby rozwiązaniem dalece nieskutecznym, skoro o tym, że taka porada została jednak udzielona można by wnioskować już tylko z tego, że dany adwokat powołał się na tajemnicę zawodową.

Zacytowany przez P. Krzyżanowskiego judykat w postaci postanowienia Sądu Apelacyjnego w Krakowie z dnia 5 sierpnia 2015 r., nota bene pozbawiony wskazania miejsca jego publikacji ${ }^{16}$, aż prosi się o uwagę, że w praktyce wymiaru sprawiedliwości rozróżnienie wiadomości posiadanych przez osobę będącą adwokatem na te, które pozyskał w toku wykonywania tego zawodu od tych, które pozyskał przy okazji pełnienia innych funkcji, jest tyleż pożądane, co nadzwyczaj trudne do przeprowadzenia. Jeśli więc sąd zechce owo rozróżnienie przeprowadzić, to i tak będzie w tym zakresie zdany przede wszystkim na prawdomówność samego depozytariusza tej tajemnicy, obawiając się zaś naruszenia zakazu dowodowego z art. 180 § 2 k.p.k., pierwej uzna poufny charakter wiadomości, niż wda się w żmudny i skomplikowany proces weryfikacji źródła jej pochodzenia. Dogłębna analiza zakresu tajemnicy adwokackiej wymaga odniesienia się do poglądu sformułowanego przed wielu już laty przez M. Cieślaka, iż wiadomości objęte tajemnicą zawodową [tu: adwokacką] należałoby podzielić na te, które zostały profesjonaliście powierzone $\mathrm{w}$ związku $\mathrm{z}$ wykonywanym przezeń zawodem i dotyczą sfery życia prywatnego osób trzecich oraz te, które dotyczą struktur organizacyjnych danej korporacji i mechanizmów jej działania ${ }^{17}$. Wiadomości składające się na drugą grupę można z powodzeniem określić mianem „sekretów” lub

\footnotetext{
${ }^{14}$ http://prawo.gazetaprawna.pl/artykuly/1273453,tajemnica-zawodowa-adwokacka-zmiany-w-pro cedurze-karnej.html [dostęp: 3.11.2018].

${ }^{15}$ A. MachnikowsKa, Tajemnica zawodowa, [w:] Granice wolności wypowiedzi przedstawicieli zawodów prawniczych, red. A. Biłgorajski, LEX/el. 2015.

${ }^{16}$ Postanowienie Sądu Apelacyjnego w Katowicach z dnia 5 sierpnia 2015 r., sygn. akt II AKz 443/15, „Biuletyn OSA w Katowicach” 3 (2015), s. 10-11. Podobnie zresztą Sąd Najwyższy w wyroku z dnia 1 grudnia 2016 r. (sygn. akt SDI 65/16, LEX nr 2182292), gdzie zauważa się, że zakres tajemnicy wyznacza przede wszystkim związek pozyskania informacji przez adwokata z wykonywaniem merytorycznych czynności zawodowych.

${ }^{17}$ M. CIEŚLAK, Zagadnienia dowodowe $w$ procesie karnym, t. I, Warszawa: Wydawnictwo Prawnicze 1955, s 271-272.
} 
„tajników zawodowych”, ważnych z punktu widzenia możliwości prawidłowego wykonywania zawodu, lecz niekoniecznie wymagających utajnienia z powołaniem się na tajemnicę zawodową danego rodzaju ${ }^{18}$. Warto tu wreszcie zauważyć, że choć zgoda klienta nie jest warunkiem zwolnienia adwokata $\mathrm{z}$ obowiązku dochowania tajemnicy, to przecież część informacji jest przekazywana adwokatowi $\mathrm{z}$ intencją ich dalszego procesowego wykorzystania, co wymaga niejednokrotnie ich ujawnienia we właściwym momencie postępowania sądowego w sposób zgodny z obraną przez adwokata i uzgodnioną z klientem taktyką prowadzenia jego sprawy.

Zwolennicy tezy o niepodzielnej i nienaruszalnej tajemnicy adwokackiej opierają swe przekonanie o takim właśnie jej charakterze na treści art. 6 ust. 2 oraz ust. 3 Pr.adw. Pierwszy z nich traktuje o niemożności ograniczenia w czasie obowiązku zachowania tej tajemnicy, drugi zaś o niedopuszczalności zwolnienia z obowiązku jej zachowania co do faktów objętych tą tajemnicą. Odnotowania wymaga, że zakaz zwolnienia z tajemnicy adwokackiej pojawił się w treści Prawa o adwokaturze stosunkowo późno, bo dopiero w dniu 15 września 1997 r. $^{19}$, wcześniej art. 6 dość oszczędnie traktował o tej tajemnicy, ograniczając się do treści, która obecnie składa się na jego ustęp pierwszy. Nawet gdyby uznać, że art. 6 ust. 3 Pr.adw. dawał przez chwilę jakieś podstawy do twierdzenia o nienaruszalności tajemnicy adwokackiej, to teza ta już zupełnie nie wytrzymuje krytyki po dniu 15 maja 2004 r., kiedy to do art. 6 dodany został nowy czwarty ustęp ${ }^{20}$, uchylający ex lege obowiązek zachowania tajemnicy adwokackiej informacji udostępnianych na podstawie przepisów ustawy z dnia 16 listopada 2000 r. o przeciwdziałaniu praniu pieniędzy oraz finansowaniu terroryzmu - w zakresie określonym tymi przepisami ${ }^{21}$. Noweli tej w kontekście nienaruszalności tajemnicy adwokackiej P. Krzyżanowski w ogóle nie omawia, a przecież przepis art. 6 ust. 4 Prawa o adwokaturze stanowi swego rodzaju biblijną belkę w oku palestry, spychając $\mathrm{w}$ niebyt tezę o niedopuszczalności uchylenia tajemnicy adwokackiej w zakresie określonym przepisem szczególnym.

\footnotetext{
${ }^{18}$ SowiŃSKI, Prawo świadka, s. 148-149.

${ }^{19}$ Art. 1 pkt 5 ustawy z dnia 22 maja 1997 r. o zmianie ustawy - Prawo o adwokaturze, ustawy o radcach prawnych oraz niektórych innych ustaw, Dz. U. Nr 75, poz. 471 z późn. zm.

${ }^{20}$ Art. 2 ustawy z dnia 5 marca 2004 r. o zmianie ustawy o przeciwdziałaniu wprowadzaniu do obrotu finansowego wartości majątkowych pochodzących z nielegalnych lub nieujawnionych źródeł oraz o przeciwdziałaniu finansowaniu terroryzmu oraz o zmianie niektórych ustaw, Dz. U. Nr 62, poz. 577.

${ }^{21}$ Ustawa $z$ dnia 16 listopada 2000 r. o przeciwdziałaniu praniu pieniędzy oraz finansowaniu terroryzmu, Dz. U. z 2003 r. Nr 153, poz. 1505, z późn. zm. - brzmienie art. 6 ust. 4 po nowelizacji przez art. 158 ustawy z dnia 1 marca 2018 r. (Dz. U. poz. 723) zmieniającej go z dniem 13 lipca 2018 r.
} 
Takim przepisem szczególnym wobec art. 6 ust. 1 Pr.adw. jest też art. $180 \S 2$ k.p.k. w zakresie, w jakim ten ostatni przewiduje zwolnienie z tajemnicy adwokackiej. Nie sposób przyjąć, że pomiędzy tymi aktami normatywnymi zachodzi relacja odwrotna, choć jest to pogląd prezentowany przez Autorów zbliżonych do środowiska adwokackiego, co zresztą zdaje się determinować sposób ich myślenia $^{22}$. Jeszcze w okresie obowiązywania art. 163 k.p.k. z 1969 r. ${ }^{23}$ próbowali oni wywodzić, że przepis ten - jako odwołujący się do „bardzo szerokiego grona osób zeznających w charakterze świadka i zasłaniających się tajemnicą [...] zawodową" - jest przepisem ogólniejszym w stosunku do przepisu szczególnego, tj. art. 6 Prawa o adwokaturze. Problem ten został dostrzeżony w niezwykle ważnym orzeczeniu Sądu Najwyższego z tego okresu, pominiętym zupełnie przez P. Krzyżanowskiego, a mianowicie: uchwale siedmiu sędziów Sądu Najwyższego z dnia 16 czerwca $1994 \mathrm{r}^{24}$ Wprawdzie przedmiotowa uchwała zapadła w odmiennym stanie prawnym, to jednak znamienne jest to, że nawet pod rządami nieobowiązującego już art. 163 k.p.k. z 1969 r., który nie wymieniał wprost tajemnicy adwokackiej, Sąd Najwyższy był w stanie wywieść, iż to przepisy kodeksowe stanowią leges speciales w stosunku do odnośnego przepisu ustawy korporacyjnej, zaś organy procesowe były władne zwolnić adwokata z obowiązku zachowania tej tajemnicy. Zupełnie kluczowe znaczenie miało przy tym wskazanie, że „bezwzględny i stanowczy zakaz” przesłuchania adwokata dotyczył tylko tej części tajemnicy adwokackiej, która wiązała się z jego działalnością obrończą. Skoro więc obrona karna miała ówcześnie stricte adwokacki charakter, a obowiązujący wtedy art. 161 pkt 1 k.p.k. z 1969 r. wprowadzał absolutny zakaz dowodowy wyłącznie co do „faktów”, o których „obrońca dowiedział się udzielając porady prawnej lub prowadząc sprawę", to wszystko to, co składało się na nieobrończą tajemnicą adwokacką mogło jednak podlegać ujawnieniu w trybie dawnego art. 163 k.p.k. Zakaz ten - jako wyjątek od reguły wyrażonej przez art. 160 k.p.k. z 1969 r. zgodnie z regułą exceptiones non sunt extendendae nie podlegał wykładni rozszerzającej, co oznaczało, że nie można nim było objąć tych adwokatów, którzy weszli $\mathrm{w}$ posiadanie określonych informacji w związku $\mathrm{z}$ ich nieobrończą działalnością zawodową. Rozwiązanie to wykazywało dużą zbieżność z rozwiązaniem znanym z art. 91 lit. b przedwojennego k.p.k. i zostało przyjęte przez Sejm pomimo apelu Naczelnej Rady Adwokackiej z dnia 7 listopada 1968 r. o zastąpienie w art. 161

\footnotetext{
${ }^{22}$ Z. KrZEmiŃSKI, Prawo o adwokaturze. Komentarz, Warszawa: Wydawnictwo C.H. Beck 1998, s. 34 oraz TENŻE, SN: tajemnica adwokacka, „Monitor Prawniczy” 10 (1994), s. 304.

${ }^{23}$ Tamże.

${ }^{24}$ Uchwała Sądu Najwyższego z dnia 16 czerwca 1994 r., sygn. akt I KZP 5/94, OSNKW 7-8 (1994), poz. 41.
} 
pkt 1 k.p.k. z 1969 r. słowa „obrońca” słowem „adwokat” użytym we właściwym przypadku. NRA zauważała, że w przeciwnym razie tajemnica adwokacka, w zakresie wykraczającym poza tajemnicę obrończą, stanie się „tajemnicą ograniczoną, ${ }^{25}$. Przez długi czas art. 6 Prawa o adwokaturze z 1982 r. powtarzał rozwiązanie znane z art. 7 ustawy o ustroju adwokatury z dnia 19 grudnia 1963 r., jednak nawet wspomniana przeze mnie wcześniej nowelizacja z 1997 r., polegająca na wprowadzeniu do tego przepisu literalnie wyrażonego zakazu („nie można”) zwolnienia adwokata od obowiązku zachowania tajemnicy adwokackiej nie zachwiała relacją zachodzącą pomiędzy tym właśnie przepisem a art. 160 pkt 1 k.p.k. oraz art. 163 k.p.k. z 1969 r. Spory wokół charakteru nieobrończej tajemnicy adwokackiej miały wszak ten skutek, że w art. 180 § 2 k.p.k. z 1997 r. pojawiło się już wyraźne odwołanie do „tajemnicy adwokackiej”, a później sukcesywnie także i do innych tajemnic zawodowych, w tym i tajemnicy radcy prawnego ${ }^{26}$. Nie sposób podzielić poglądu, jakoby o ogólniejszej naturze art. 180 § 2 k.p.k. miał rozstrzygać fakt posłużenia się w nim terminem „osoba”, nie zaś „,adwokat”, gdyż indywidualizacja adresata następuje poprzez dookreślenie obowiązku, jaki na tej właśnie osobie spoczywa. Bez wątpienia więc „osobą, zobowiązaną do zachowania tajemnicy [...] adwokackiej" jest adwokat (aplikant adwokacki), podobnie jak wymienioną w art. $180 \S 2$ k.p.k. ,osobą zobowiązaną do zachowania tajemnicy [...] radcy prawnego" jest ten właśnie radca prawny (aplikant radcowski), a nie ktoś inny. Tej oczywistości nie dostrzegał swego czasu ani Z. Krzemiński $^{27}$, ani S. Śliwiński ${ }^{28}$, przy czym ten ostatni Autor miał jeszcze pewne podstawy do takiego twierdzenia, gdyż pogląd ten sformułował pod rządami art. 102 k.p.k. z 1928 r., który traktował ogólnikowo o ,świadku odmawiającym zeznań z powodu tajemnicy zawodowej”. Chcąc uniknąć dalszych spekulacji co do wzajemnego stosunku normy karnoprocesowej do normy korporacyjnej, E. Kruk postuluje uzupełnienie art. 6 ust. 3 Pr.adw. o zwrot wskazujący na prymat art. 180 $\S 2$ k.p.k. ${ }^{29}$ Nawet jednak bez interwencji ustawodawcy każdy, kto obiektywnie ocenia relacje zachodzące pomiędzy art. $180 \S 2$ k.p.k. a art. 6 ust. 3 Pr.adw. jest

\footnotetext{
${ }^{25}$ Uchwała Prezydium NRA z dnia 7 listopada 1968 r., [w:] http://bazhum.muzhp.pl/media//fi les/Palestra/Palestra-r1969-t13-n1(133)/Palestra-r1969-t13-n1(133)-s106-111/Palestra-r1969-t13-n1(133)s106-111.pdf [dostęp: 5.11.2018].

${ }^{26}$ Obecnie - obok tajemnicy adwokackiej - jest tam mowa także o tajemnicy lekarskiej i dziennikarskiej (1997), radcy prawnego (2000), notarialnej (2003), doradcy podatkowego (2010), statystycznej (2013) oraz tajemnicy Prokuratorii Generalnej (2017).

${ }^{27}$ Z. KRZEMIŃSKI, Wystapienie przed SN na posiedzeniu w dniu 16 czerwca $1994 \mathrm{r}$. poprzedzającym wydanie uchwaty 7 sędziów SN, „Palestra” 9-10 (1994), s. 67 n.

${ }^{28}$ S. ŚLIWIŃSKI, Proces karny. Zasady ogólne, Warszawa: Gebethner i Wolff 1948, s. 641-641.

${ }^{29}$ KRUK, Obowiazek zachowania, s. 28.
} 
w stanie przyznać, że ewentualne uchylenie obowiązku zachowania tajemnicy adwokackiej na potrzeby sprawy karnej nie można rozpatrywać w kategorii „,bezpodstawnego łamania" tej tajemnicy ${ }^{30}$.

Przejawem szczególnego charakteru art. 180 § 2 k.p.k. jest wreszcie i to, że w warunkach procesowych uprawnia on depozytariusza tajemnicy adwokackiej i innych tam wymienionych tajemnic zawodowych do odmowy zeznań co do okoliczności immunizowanych, podczas gdy żadna $\mathrm{z}$ ustaw korporacyjnych o takim uprawnieniu nie stanowi. Prawo to wynika pośrednio z art. $180 § 2$ k.p.k. Mimo, że prawo do odmowy zeznań nie jest tam zapisane w sposób wyraźny, to trudno przyjąć, że w razie podjęcia przez organ procesowy próby przesłuchania adwokata przed uzyskaniem formalnego zwolnienia go z tajemnicy zawodowej miałoby mu przysługiwać jakieś inne uprawnienie, niż to wzorowane na uprawnieniu któregoś z zawodowców wymienionych w art. 180 § 1 k.p.k. Z omawianego tu art. $180 \S 2$ k.p.k. wynika wreszcie i to, że warunkiem przesłuchania osób objętych nakazem poufności w zakresie wyznaczonym którąś ze wskazanych w tym przepisie tajemnic zawodowych jest ich uprzednie zwolnienie z tego obowiązku. Implikuje to niemożność samorzutnego złożenia przez świadka zeznań odnośnie do faktów objętych np. tajemnicą adwokacką.

\section{TAJEMNICA ADWOKACKA A TAJEMNICA OBROŃCZA}

Choć w powszechnym odczuciu synonimem „obrońcy oskarżonego” jest słowo ,adwokat”, to od daty dopuszczenia przez przepis art. 82 k.p.k. do pełnienia funkcji obrońcy w procesie karnym także niektórych radców prawnych ${ }^{31}$, jest to mniemanie błędne. O ile adwokaci mają prawo pełnić rolę obrońcy bez ograniczeń, o tyle radców dotyka ograniczenie z art. 6 ust. 1 in fine $\mathrm{w}$ zw. z art. 8 ust. 6 ustawy o radcach prawnych, tj. w sprawach o przestępstwa i przestępstwa skarbowe nie może jej pełnić osoba pozostająca w stosunku pracy, co jednak nie dotyczy radców prawnych zatrudnionych w charakterze pracowników naukowych i naukowo-dydaktycznych.

Pozbawienie obrony karnej w sprawach o przestępstwa cech obrony stricte adwokackiej musiało się odbić także na sposobie karnoprocesowego podejścia do zagadnienia tajemnicy obrończej z art. 178 pkt 1 k.p.k., która od lipca 2015 r.

\footnotetext{
${ }^{30}$ M. SMARZEWSKI, M. BANACH, Ochrona tajemnicy $w$ procesie karnym $w$ zwiazku z czynnościami przestuchania i przeszukania, „Palestra” 3 (2017), s. 75.

${ }^{31}$ Por. art. 1 pkt 27 ustawy z dnia 27 września 2013 r. o zmianie ustawy - Kodeks postępowania karnego oraz niektórych innych ustaw (Dz. U. poz. 1247) zmieniającej ustawę z dniem 1 lipca 2015 r.
} 
może być rozpatrywana jako składowa tajemnicy adwokackiej albo tajemnicy radcowskiej sensu largo, co jednak nie wyczerpuje wszystkich możliwości. Tajemnica obrończa rozważana na tle art. 178 pkt 1 k.p.k. jawi się bowiem jako problem dużo bardziej złożony i wykraczający poza problematykę wykonywania zawodu adwokackiego lub radcowskiego. Niewskazanie w tym przepisie, że chodzi wyłącznie o „obrońcę oskarżone g o" lub o „obrońcę w s praw i e k a r n e j” powoduje, że przepis ten immunizuje wiadomości podmiotu pełniącego funkcję obrońcy w każdym dopuszczonym przez ustawę postępowaniu ${ }^{32}$, przy czym nie musi to być wcale postępowanie sądowe. Przede wszystkim może tu chodzić o obrońcę obwinionego z art. 4 k.p.w. ${ }^{33}$, ale też „obrońcą” w rozumieniu art. 178 pkt 1 k.p.k. może być np. prokurator lub sędzia ustanowiony przez obwinionego prokuratora w trybie art. 156 ust. 1 Prawa o prokuraturze ${ }^{34}$ lub obwinionego sędziego sądu wojskowego w trybie art. 40 § 6 Prawa o ustroju sądów wojskowych $^{35}$, a nawet notariusz ustanowiony przez obwinionego notariusza w trybie art. 56 Prawa o notariacie ${ }^{36}$ - na użytek prowadzonych przeciwko nim postępowań dyscyplinarnych. Pogląd ten $\mathrm{w}$ doktrynie akceptuje m.in. T. Grzegorczyk ${ }^{37}$, D. Gruszecka ${ }^{38}$ i M. Kurowski ${ }^{39}$. Nic nie stoi na przeszkodzie, aby za „obrońcę” w rozumieniu art. 178 pkt 1 k.p.k. uznać lekarza, który pełni tę rolę na podstawie art. 58 ust. 2 ustawy o izbach lekarskich ${ }^{40} \mathrm{w}$ czasie postępowania w przedmiocie odpowiedzialności zawodowej innego lekarza obwinionego o naruszenie zasad etyki lekarskiej oraz przepisów związanych z wykonywaniem tego zawodu.

P. Krzyżanowski, choć prawidłowo różnicuje zakres ochrony obu tajemnic, tzn. adwokackiej i obrończej, to pisze o tej ostatniej, jakby była ona instytucją homogeniczną, a traktujący o niej art. 178 § 1 k.p.k. nie wykazywał żadnej złożoności. A przecież przepis ten chroni nie tylko „czystą” tajemnicę obrończą (karną i/lub dyscyplinarną), lecz także i tajemnicę ,,adwokata lub radcy prawnego działających na podstawie art. $245 \S 1$ [k.p.k. - P.K.S.]”, co oznacza, że ustawodawca

\footnotetext{
${ }^{32}$ Taki zwrot był stosowany przez art. 101 lit. b k.p.k. z 1928 r. (wedle numeracji pierwotnej).

${ }^{33}$ Ustawa z dnia 24 sierpnia 2001 r. Kodeks postępowania w sprawach o wykroczenia, Dz. U. z 2018 r., poz. 475 z późn. zm.

${ }^{34}$ Ustawa z dnia 28 stycznia 2016 r. Prawo o prokuraturze, Dz. U. z 2017 r., poz. 1767 z późn. zm.

${ }^{35}$ Ustawa z dnia 21 sierpnia 1997 r. Prawo o ustroju sądów wojskowych, Dz. U. z 2018 r., poz. 1921.

${ }^{36}$ Ustawa z dnia 14 lutego 1991 r. Prawo o notariacie, Dz. U. z 2017 r., poz. 2291 z późn. zm.

${ }^{37}$ T. GRZEGORCZYK, Kodeks postępowania karnego. Komentarz do art. 1-467, t. I, Warszawa: Wolters Kluwer 2014, s. 612-613.

${ }^{38}$ D. GRUSZECKA, Komentarz do art.174, [w:] Kodeks postepowania karnego. Komentarz, red. J. Skorupka, Warszawa: Wydawnictwo C.H. Beck 2015, s. 413.

${ }^{39}$ M. KurowsKI, Komentarz do art. 178 k.p.k., LEX/el. 2018, teza 2.

${ }^{40}$ Ustawa z dnia 2 grudnia 2009 r. o izbach lekarskich, Dz. U. z 2018 r., poz. 168 z późn. zm.
} 
nie zalicza ich do grupy „obrońców” nawet tak szeroko potraktowanych, jak ma to miejsce w art. 178 pkt 1 k.p.k. Dzieje się tak, gdyż przepis art. $245 \S 1$ k.p.k. traktuje o prawie zatrzymanego, nie zaś podejrzanego lub o s k a r ż o n e g o, do „nawiązania w dostępnej formie kontaktu z adwokatem lub radcą prawnym, a także bezpośrednią z nimi rozmowę". Skoro w art. $245 \S 1$ k.p.k. jest mowa o „zatrzymanym”, to jest to pojęcie różne od tego, którym posługuje się art. 6 w zw. z art. w zw. z art. $71 \S 3$ k.p.k. Tym samym zazwyczaj zatrzymanemu nie służy jeszcze prawo do obrony formalnej, tj. skorzystania - wedle jego wyboru $-\mathrm{z}$ pomocy adwokackiego lub radcowskiego obrońcy. Wprawdzie prawnik, udzielający zatrzymanemu pomocy w trybie art. $245 \S 1$ k.p.k., musi być adwokatem lub radcą prawnym, jednak w chwili przystąpienia do jej udzielenia nie jest obrońcą zatrzymanego ${ }^{41}$ i wcale nie musi stać się nim później, aczkolwiek taka ewentualność może zajść $\mathrm{w}$ razie podjęcia wobec tego zatrzymanego czynności w trybie art. $308 \S 2$ lub $313 \S 1$ k.p.k. Może się zdarzyć, że rozmowa przeprowadzona z zatrzymanym odbędzie się na przedpolu obrony karnej, nie jest to jednak regułą. Organ prowadzący postępowanie przygotowawcze może bowiem uznać, że w stosunku do zatrzymanego nie zachodzi jednak ,dostatecznie podejrzenie, że [popełnił on - P.K.S.] czyn" lub też zatrzymany - po uzyskaniu statusu właściwej strony procesowej - zechce skorzystać z usług innego adwokata lub radcy prawnego. Dyferencja ta nie pozwala na określenie tajemnicy takiego adwokata lub radcy prawnego mianem „tajemnicy obrończej”, pomimo że jest ona chroniona równie mocno ${ }^{42}$, a obejmujący tę tajemnicę zakaz dowodowy jest także zaliczany $\mathrm{w}$ doktrynie do zakazów niezupełnych bezwzględnych ${ }^{43}$ lub bezwzględnych zakazów dowodzenia za pomocą określonego dowodu ${ }^{44}$, co oznacza niemożność skorzystania z określonego w nim źródła dowodowego dotyczącego określonej okoliczności. W doktrynie słusznie więc określa się ją tajemnicą quasi-obrończą.

Szerokie potraktowanie przez art. 178 pkt 1 k.p.k. tajemnicy obrończej, która w rozumieniu tego przepisu może być tajemnicą adwokacką, radcowską i tajemnicą obrońcy występującego $\mathrm{w}$ przewidzianym przez prawo postępowaniu innym niż karne, tłumaczy dlaczego do jej wyróżnienia dochodzi na gruncie kodeksowym, nie zaś np. ustawy Prawo o adwokaturze. Jest to bowiem tajemnica związana $\mathrm{z}$ wykonywaniem nie tyle określonego zawodu prawniczego, co określonej

\footnotetext{
${ }^{41}$ GRZEGORCZYK, Kodeks, s. 875.

${ }^{42}$ Można tu mówić o „zrównaniu w tym zakresie [z obrońcą]” adwokata lub radcy prawnego działających w trybie art. $245 \S 1$ k.p.k. Tak: GRZEGORCZYK, Kodeks, s. 612.

${ }^{43}$ J. Tylman, T. GRZEGORCZYK, Polskie postępowanie karne, Warszawa: Wolters Kluwer 2011, s. 439.

${ }^{44}$ KWIATKOWSKI, Zakazy, s. 125.
} 
funkcji procesowej wyodrębnionej na bazie stosunków procesowych zachodzących pomiędzy uczestnikami określonego rodzaju postępowania (in hoc casu - funkcji obrony). Sama ustawa Prawo o adwokaturze traktuje o obronie dość zdawkowo i to wyłącznie w kontekście nadużycia wolności słowa (art. 8 ust. 2), dopuszczalności pełnienia zastępstwa przez aplikanta adwokackiego (art. 77 ust. 3) oraz kwestii związanych z postępowaniem dyscyplinarnym (dział VIII). Wskazanie, iż bezwzględność tajemnicy adwokackiej miałaby umacniać prawo do obrony jest nieuprawnione, nie tylko dlatego, że art. 178 pkt 1 k.p.k. absolutyzuje tajemnicę adwokacką w zakresie, w jakim pokrywa się ona z tajemnicą obrończą ${ }^{45}$, lecz także dlatego, że tajemnica obrończa może być zarazem tajemnicą nieadwokacką.

Tajemnicą obrończą objęte są informacje uzyskane w związku z pełnioną funkcją obrończą. Przepis art. 178 pkt 1 k.p.k. chroni „fakty, o których [obrońca P.K.S.] dowiedział się udzielając porady prawnej lub prowadząc sprawę", niezależnie od tego, kto był źródłem odnośnej informacji. Jest to więc rozwiązanie znacznie korzystniejsze dla osób zainteresowanych ich utajnieniem od tego, które znane było przepisowi art. 101 lit. b przedwojennego k.p.k., gdzie ochronie podlegały informacje uzyskane tylko od tego właśnie oskarżonego („od niego”). Z powyższych względów kuriozalnie brzmi postulat, aby „zlikwidować [na gruncie postępowania karnego - P.K.S.] tajemnicę obrończą", pozostawiając w nim wyłącznie tajemnicę adwokacką, gdyż w ten sposób ta ostatnia uległaby wzmocnieniu (s. 47). Co w takim razie miałoby się stać z tajemnicą obrończą nieadwokacką, tego już Autor nie raczył nam wyjaśnić... ${ }^{46}$

\section{CZYNNOŚCI DOWODOWE PODEJMOWANE W STOSUNKU DO OSOBY WYKONUJĄCEJ ZAWÓD ADWOKATA}

P. Krzyżanowski pisze, że przesłuchanie co do okoliczności objętych tajemnicą adwokacką jest czynnością, podczas której tajemnica ta jest „najbardziej narażona

\footnotetext{
${ }^{45}$ M. RUSINEK, Tajemnica zawodowa i jej ochrona w polskim procesie karnym, Kraków: Wolters Kluwer 2007, s. 137.

${ }^{46}$ Gwoli ścisłości równie nieprzemyślane są „cząstkowe” propozycje wyłączenia spod działania art. $180 \S 2$ k.p.k. adwokatów niebędących obrońcami i objęcia ich dyspozycją art. 178 pkt 1 k.p.k. Zgłaszająca ów postulat E. Mądrecka w ogóle nie odnosi się do sytuacji radców prawnych i innych profesjonalistów wymienionych w pierwszym z tych przepisów, tak jakby tylko tajemnica adwokacka była tajemnicą wartą szczególnego potraktowania. Zob.: W kwestii kolizji art. 180 § 2 kodeksu postępowania karnego $i$ art. 6 Prawa o adwokaturze, „Nowa Kodyfikacja Prawa Karnego” 28 (2012), s. 158.
} 
na ujawnienie" (s. 36), co wydaje mi się rozpoznaniem nie do końca poprawnym, zważywszy na fakt, że w trakcie takiego przesłuchania adwokat dysponuje jednak dość skutecznym środkiem w postaci odmowy zeznań. Wprawdzie o takiej „odmowie" przepis art. $180 \S 2$ k.p.k. nic nie wspomina, to jednak do czasu rozstrzygnięcia przez sąd kwestii związanych ze zwolnieniem adwokata z obowiązku zachowania przedmiotowej tajemnicy, musi on w jakiś sposób chronić jej integralność. Wydaje się, że jedynym sposobem, w jaki może to uczynić jest wskazanie organowi przesłuchującemu niejawnej proweniencji pewnych faktów i w ślad za tym uchylić się od odpowiedzi na dotyczące ich pytanie lub - szerzej - uchylić się od zeznań. $Z$ całą pewnością znacznie skuteczniejsze będzie wskazanie, że badane fakty objęte są tajemnicą obrończą (adwokacką lub nieadwokacką); w takim bowiem wypadku nie ma sposobu obejścia zakazu dowodowego z art. 178 pkt 1 k.p.k. w stosunku do osoby indagowanej. Choć sam nie jestem „wyznawcą” tezy o dopuszczalności niestawiennictwa osoby wymienionej w art. 178 pkt 1 k.p.k. przed organem wzywającym, to - jak słusznie zauważa Autor - zyskała ona swoich zwolenników w nauce prawa karnego procesowego (s. 36).

Ewentualne zwolnienie świadka z obowiązku zachowania tajemnicy zawodowej jest skuteczne wyłącznie w obrębie postępowania karnego, w ramach którego zapadło odnośne postanowienie sądowe. Nie można się więc na nie powoływać w innych, równolegle prowadzonych sprawach, choćby nawet były one powiązane ze sprawą, w której owego zwolnienia dokonano. Postanowienie sądu powinno precyzować zakres tego zwolnienia, samo zwolnienie nie może bowiem przybrać zwolnienia generalnego z tajemnicy adwokackiej.

Ten sam Autor zbyt wąsko ujął problematykę przesłuchania, sprowadzając je wyłącznie do czynności prowadzonej z udziałem adwokata występującego w roli świadka, podczas gdy czynność tę można prowadzić z udziałem adwokata podejrzanego lub oskarżonego w sprawie. P. Krzyżanowski możliwości tej nie rozpoznaje, a przecież nie są to niestety sytuacje tak rzadkie. Ponieważ art. $180 § 2$ k.p.k. zamieszczono w rozdziale 21. Kodeksu postępowania karnego, który jest poświęcony „świadkom”, stąd też dylemat, jak postąpić w wypadku, gdy fakty objęte tajemnicą (inną zawodową) miałby ujawnić podejrzany lub oskarżony. Czy takie przesłuchanie winno poprzedzać zwolnienie wzorowane na tym, o którym mowa w art. $180 § 2$ k.p.k., a jeśli nie to, czy składający w tym zakresie podejrzany lub oskarżony naraża się na odpowiedzialność z tytułu ujawnienia poufnych danych? Ponieważ kwestie te już raz szczegółowo wyjaśniałem, dla porządku wspomnę jedynie, że prawo do obrony nie zna w tym zakresie żadnego ograniczenia, stąd też uważam, że adwokat podejrzany lub oskarżony w sprawie może 
w swoich wyjaśnieniach podać fakty chronione tajemnicą adwokacką bez wyczekiwania na odrębne zwolnienie go z obowiązku jej zachowania ${ }^{47}$. Nie da się do sytuacji takiego adwokata zastosować per analogiam przepisu art. $180 \S 2$ k.p.k., który jako przepis wyjątkowy nie powinien być wykładany w taki sposób. Z całą jednak pewnością taki adwokat winien przed rozpoczęciem składania wyjaśnień w zakresie immunizowanych faktów uprzedzić sąd o zarysowującym się ryzyku ujawnienia poufnych danych, co pozwoliłoby temu organowi wyprzedzająco wyłączyć jawność tej części rozprawy w trybie art. $360 \S 1$ pkt 1 lit. d k.p.k. ze względu na przesłankę ,,naruszenia ważnego interesu prywatnego”.

P. Krzyżanowski pisze o etycznej stronie wykonywania zawodu adwokackiego oraz wpisaniu tego zawodu w system wymierzania sprawiedliwości, uznając że z tego powodu nie można tajemnicy adwokackiej uchylać z powołaniem się na dobro tego samego systemu. A przecież art. $180 \S 2$ k.p.k. zasadza się nie na automatyzmie stosowania, lecz na ważeniu racji przemawiającej za takim zwolnieniem w sprawach ważkich i odmowie takiego zwolnienia w sprawach o małej wadze, co widać w szeregu judykatów przytoczonych przez tego samego Autora. Nie mam pojęcia, skąd pomysł przypisania klauzuli ,dobra wymiaru sprawiedliwości” cechy „polityczności” (s. 38), skoro wymiar ten w jego modelowym ujęciu charakteryzuje „niezawisłość” oraz ,apolityczność”, co przekładać się powinno na treść decyzji zapadających w toku całego procesu karnego. Tym samym adwokatom przeszkadza normatywnie uregulowane zwolnienie $\mathrm{z}$ tajemnicy adwokackiej, nie zgłaszają natomiast obiekcji w stosunku do obłożenia ich wewnątrzkorporacyjnym zakazem ,zgłaszania dowodu z zeznań świadka będącego adwokatem lub radcą prawnym [na zasadzie zresztą wzajemności - uwaga moja P.K.S.] w celu ujawnienia przez niego wiadomości uzyskanych w związku z wykonywaniem zawodu" ( $\$ 19$ ust. 8 Zbioru Zasad Etyki Adwokackiej ${ }^{48}$ ). Tymczasem zakaz ów jest wyraźnym ograniczeniem ich ,pełnej swobody i niezależności” (§ 7 zd. 1), kolidującym z nakazem wykonywania czynności zawodowych „,zgodnie z najlepszą wolą i wiedzą" ( $\$ 8 \mathrm{zd}$. 1). Jak reprezentować w optymalny sposób interes klienta, jeśli już na wstępie adwokatowi wiąże się ręce, nie zezwalając mu na powołanie dowodu z zeznań innego palestranta, choćby miał on zupełnie zasadnicze znaczenie w sprawie? Czy taka sytuacja nie rodzi owego „konfliktu war-

\footnotetext{
${ }^{47}$ P.K. SOwIŃSKI, Uprawnienia składające się na prawo oskarżonego do obrony. Uwagi na tle czynności organów procesowych oraz oskarżonego, Rzeszów: Wydawnictwo Uniwersytetu Rzeszowskiego 2012, s. $630 \mathrm{n}$.

${ }^{48}$ Zbiór Zasad Etyki Adwokackiej i Godności Zawodu (Kodeks Etyki Adwokackiej) uchwalony przez NRA w dniu 10 października 1998 r. (2/XVIII/98) i stanowiący załącznik do obwieszczenia Prezydium NRA z dnia 27 lutego 2018 r. w sprawie ogłoszenia jego tekstu jednolitego.
} 
tości” (s. 46), przed którym chce się bronić adwokatów, znosząc możliwość sądowego uchylenia tajemnicy zawodowej?

Osobnego omówienia wymaga również kwestia kontroli i utrwalania rozmów podejmowanych w trybie art. $237 \S 1$ k.p.k. w stosunku do adwokata (s. 44-45). Czynność ta w pierwszym rzędzie godzi w konstytucyjnie chronione przez art. 49 Konstytucji $\mathrm{RP}^{49}$ prawo do wolności i ochrony komunikowania (tzw. „tajemnica komunikowania się" $)^{50}$, prawo do prywatności, o którym stanowi art. 47 ustawy zasadniczej, a dopiero w dalszej kolejności w tajemnicę adwokacką i każdą inną tajemnicę zawodową. W doktrynie nie ma zgodności co do tego, czy kontrola taka jest dopuszczalna w stosunku do osób zobowiązanych do zachowania tajemnicy zawodowej, w tym adwokackiej. Z całą pewnością żaden z przepisów rozdziału 27. obecnego k.p.k. nie zawiera wskazania, iż osoby te należałoby traktować w jakiś odmienny sposób, niż resztę obywateli ${ }^{51}$. Nie oznacza to wcale przyzwolenia na ich podsłuchiwanie w sposób nieograniczony, gdyż mogłoby to prowadzić do obejścia zakazu z art. 180 § 2 k.p.k. Problem dopuszczalności kontroli i utrwalania rozmów prowadzonych przez adwokata i innych profesjonalistów próbuje się więc rozwiązać w doktrynie na dwa sposoby. I tak dopuszcza się stosowanie podsłuchu na zasadach ogólnych wobec osoby wykonującej któryś z zawodów wymienionych w art. $180 \S 2$ k.p.k., jeżeli środek ten jest stosowany bez związku z tym zawodem i tajemnicą. Natomiast, gdy podsłuch mający na celu ingerencję $\mathrm{w}$ sferę immunizowaną przez tajemnicę zawodową określonego rodzaju może być stosowany po spełnieniu warunków z art. 237 k.p.k. i dodatkowo przesłanek odnoszących się do zwolnienia z tej tajemnicy określonych w art. $180 \S 2$ i 3 k.p.k. ${ }^{52} \mathrm{~W}$ ślad za tym zakłada się również niemożność kontrolowania rozmów prowadzonych przez obrońcę i quasi-obrońcę. Pogląd ten wyraża m.in. K. Dud$\mathrm{ka}^{53}$, natomiast G. Musialik dostrzega możliwość ograniczenia dopuszczalności stosowania podsłuchu wobec osób zobowiązanych do zachowania tajemnicy zawodowej w drodze odwołania się do zasady proporcjonalności, zakazującej stosowanie środków powodujących „,szkody oczywiście nieproporcjonalne do za-

\footnotetext{
${ }^{49}$ Konstytucja Rzeczypospolitej Polskiej z dnia 2 kwietnia 1997 r., Dz. U. Nr 78, poz. 483 z późn. zm.

${ }^{50}$ M. Rogalski, Podstuch procesowy i pozaprocesowy, mps złożony do druku, Warszawa: Wolters Kluwer, s. 11.

${ }^{51}$ S. SteInBORn, Komentarz do art. 237 k.p.k., LEX/el. 2016, teza 7.

${ }^{52}$ K. EichSTAEDT, Komentarz do art. 237 k.p.k., LEX/el. 2018, teza 24.

${ }^{53}$ K. DUDKA, Kontrola korespondencji i podstuch $w$ polskim procesie karnym, Lublin: Wydawnictwo UMCS 1998, s. 78-79.
} 
mierzonego skutku"54. Rozwiązanie, zakładające odpowiednie stosowanie reguł odnoszących się do świadka, ma niewątpliwie walor gwarancyjny i stanowi próbę wyjścia z impasu spowodowanego brakiem wyraźnej regulacji ustawowej w tym zakresie. Słabością tego rozwiązania jest pozbawienie zainteresowanych podmiotów możliwości skutecznego zablokowania tego typu działań w drodze zażalenia i poddania ich apriorycznej kontroli instancyjnej, co uniemożliwia odroczenie ogłoszenia postanowienia o zarządzeniu kontroli i utrwalenia rozmów osobie, której ono dotyczy „,na czas niezbędny ze względu na dobro sprawy”, nie dłużej jednak niż do zakończenia postępowania, w ramach którego taka kontrola została ustanowiona (art. 239 § 1 i 2 k.p.k.). Odroczenie to, jakkolwiek celowe z punktu widzenia skuteczności zarządzonej kontroli, powoduje, że - w przeciwieństwie do kontroli przeprowadzanej w trybie art. $180 \S 2$ zd. ostatnie k.p.k. - kontrola podejmowana na podstawie art. 240 k.p.k. jest z reguły kontrolą następczą, tj. nieprzeciwdziałającą niezasadnym przypadkom naruszenia odnośnej tajemnicy. Dodatkowe problemy rodzi możliwość prowadzenia odnośnej kontroli w trybie „nagłym” (,niecierpiącym zwłoki”) z powołaniem się na decyzję prokuratorską zapadłą na podstawie art. 237 $\S 2$ k.p.k. Na koniec trzeba zauważyć, że kwestia dopuszczalności stosowania kontroli podmiotów objętych nakazem poufności stanowiła przedmiot refleksji ze strony Trybunału Konstytucyjnego, który w wyroku z dnia 30 lipca 2014 r. ${ }^{55}$ stwierdził, że obowiązujące przepisy nie dają podstaw „bezwarunkowego wyodrębnienia jakiejkolwiek kategorii podmiotów spod dopuszczalności objęcia [ich - P.K.S.] czynnościami operacyjno-rozpoznawczymi, $\mathrm{w}$ tym pozyskiwania informacji $\mathrm{w}$ trybie kontroli operacyjnej”. Zwraca się tam uwagę, że Konstytucja RP „,nie przewiduje w tym zakresie żadnych podmiotowych wyłączeń”, co „nie oznacza [...] bynajmniej dopuszczalności pozyskiwania informacji w takim trybie od wszystkich osób w jednakowym stopniu i na jednakowych zasadach"56.

Ostatnią czynnością dowodową, która może doprowadzić do ingerencji w tajemnicę adwokacką jest przeszukanie. Wprawdzie przepisy kodeksowe nie immunizują przestrzeni zajętej pod kancelarie adwokackie, to jednak złożenie przez osobę, u której czynność tę się dokonuje, oświadczenia, że wydane lub znalezione przy przeszukaniu pismo lub inny dokument zawiera informacje lub wiadomości objęte tajemnicą zawodową (tu: adwokacką), rodzi po stronie organu przeszuku-

\footnotetext{
${ }^{54}$ G. MUSIALIK, Dopuszczalność stosowania podstuchu telekomunikacyjnego w stosunku do osób zobowiazanych do zachowania tajemnicy zawodowej na gruncie Kodeksu postepowania karnego z 1997 roku, „Palestra” 11-12 (1998), s. 90; zob. także: RoGalski, Podstuch, s. 35-38.

${ }^{55}$ Wyrok Trybunału Konstytucyjnego z dnia 30 lipca 2014 r., sygn. akt K 23/11, LEX nr 1491305.

${ }^{56}$ Tamże.
} 
jącego obowiązek niezwłocznego przekazania pisma lub innego dokumentu bez jego odczytania prokuratorowi lub sądowi w opieczętowanym opakowaniu. Stanowiący o tym art. $225 \S 1$ k.p.k. nie określa celu takiego ,przekazania”, co rodzi pytanie, czy chodzi tu o zbadanie tych pism lub dokumentów pod kątem zgodności ze złożonym oświadczeniem, czy też raczej o ich zabezpieczenie do czasu rozstrzygnięcia o ich dowodowym wykorzystaniu bez uprzedniego zapoznania się z ich treścią. Nie ulega wszakże wątpliwości, że zgodnie z art. 226 k.p.k. wykorzystanie dokumentów zawierających informacje niejawne lub tajemnicę zawodową, jako dowodów w postępowaniu karnym, jest możliwe wyłącznie w drodze odpowiedniego zastosowania „w [tej - P.K.S.] kwestii” zakazów i ograniczeń określonych w art. 178-181 k.p.k. ${ }^{57}$ Oznacza to, że poziom karnoprocesowego zabezpieczenia tajemnicy adwokackiej jest identyczny niezależnie od „nośnika”, na jakim doszło do jej utrwalenia. W ten sam sposób chroni się pamięć adwokata, jak i wytworzone przezeń pisma lub dokumenty, zarówno w wersji papierowej, jak i elektronicznej. Jest to rozwiązanie spójne wewnętrznie, sprzeciwiające się jakimkolwiek próbom ominięcia zakazu z art. 180 § 2 k.p.k. Wracając do kwestii uprawnienia sądu do wstępnej klasyfikacji przekazanych mu w trybie art. $225 \S 1 \mathrm{zd}$. ostatnie k.p.k. ,pism lub innych dokumentów”, jako zawierających tajemnicę zawodową, należy zauważyć, że brak jest wyraźnego wskazania ustawowego, że badania takie może on jednak przeprowadzić. Taki tryb weryfikacji przewidziano wyłącznie w stosunku do „pism lub innych dokumentów obejmujących okoliczności związane z wykonywaniem funkcji obrońcy", jeżeli oświadczenie o obrończej proweniencji złożyła „niebędąca obrońcą” osoba, od której żąda się wydania rzeczy lub u której dokonuje się przeszukania (art. 225 § 3 k.p.k.) i tylko w przypadku, gdy oświadczenie tej osoby budzi wątpliwości. Złożenie przedmiotowego oświadczenia przez obrońcę jest zarazem nieweryfikowalne i wiążące co do „obrończej” natury zatrzymywanych pism i innych dokumentów. Przekazanie „tych dokumentów" winno nastąpić z zachowaniem rygorów określonych w art. $225 \S 1$ k.p.k., przy czym z niewiadomych przyczyn ustawodawca pomija kwestię przekazania „pism” i „rzeczy”, choć wcześniej wymienia się je w jednym rzędzie z ,innymi dokumentami”. Organem, któremu przekazuje się te dokumenty, jest sąd. Ten - po zapoznaniu się z nimi - zwraca je w całości lub w części, z zachowaniem rygorów określonych w art. $225 \S 1$ k.p.k., osobie, od której je zabrano, albo wydaje postanowienie o ich zatrzymaniu dla celów postępowania. Zasadniczym problemem, jaki pojawia się na gruncie art. $225 \S 3$ k.p.k. jest niedookreślenie „osoby, od

\footnotetext{
${ }^{57}$ Jednakże w postępowaniu przygotowawczym o wykorzystaniu, jako dowodów, dokumentów zawierających tajemnicę lekarską decyduje prokurator.
} 
której żąda się wydania rzeczy lub u której dokonuje się przeszukania”. Wydaje się, że wskazanie, iż chodzi o osobę „niebędącą obrońcą” stawia poza nawiasem nawet te osoby, które z racji zatrudnienia w kancelarii mają niesporną wiedzę co do charakteru „pism lub innych dokumentów” i ich związku z obroną. Pozytywnie należy wszak ocenić ten mianowicie fakt, że w art. 225 § 3 k.p.k. jest mowa o „obrońcy”, a nie o „obrońcy o s k a r ż o n e g o”, gdyż w ten sposób immunizowane są „pisma lub inne dokumenty" wytworzone na użytek obrony sprawowanej w szerszym, nie tylko karnoprocesowym, znaczeniu. Jest to więc rozwiązanie korespondujące z ujęciem „obrońcy” przez art. 178 pkt 1 k.p.k.

\section{UWAGI KOŃCOWE}

Pisząc o poufności relacji obrońcy w sprawach karnych z oskarżonym należało odnieść się do regulacji zawartej w art. 73 § 1 k.p.k., gdyż jest to przepis o zasadniczym znaczeniu dla kwestii zapewnienia odpowiednich warunków dla utrzymania kontaktów z tą grupą oskarżonych, która jest tymczasowo aresztowana. Z perspektywy obranego przez P. Krzyżanowskiego tematu powinien On więc ustosunkować się do możliwości zastrzeżenia przez prokuratora obecności jego samego lub innej „upoważnionej” osoby przy widzeniu z obrońcą (§ 2) oraz wpływu, jaki wywiera taka obecność na swobodę kontaktu oskarżonego z obrońcą, czego Autor nie czyni. A przecież w doktrynie uznaje się tę sytuację za przykład „odstępstwa od zasady poufności” i ,istotnego ograniczenia prawa [...] do niekontrolowanego porozumiewania się ze swoim obrońcą, ${ }^{, 5}$. P. Krzyżanowski nie wzmiankuje nawet o dopuszczalności zastrzeżenia „w szczególnie uzasadnionych wypadkach” kontroli korespondencji podejrzanego z obrońcą, choć przepis art. 73 § 3 k.p.k. również posługuje się nieostrą przesłanką ,dobra postępowania przygotowawczego”.

Podobnie ogólnikową przesłanką posługuje się zresztą wspomniany art. $73 \S 1$ oraz art. $245 \S 1$ k.p.k. Ten ostatni przepis uprawnia zatrzymującego do zawarowania $\mathrm{w}$ trakcie kontaktu zatrzymanego $\mathrm{z}$ adwokatem lub radcą prawnym swojej przy tym obecności. Początkowo art. $245 \S 1$ k.p.k. pozwalał zatrzymującemu na korzystanie z tego uprawnienia w sposób niczym nieograniczony, co zostało zakwestionowane przez Trybunał Konstytucyjny w wyroku z dnia 11 grudnia 2012 r. $^{59}$, jako regulacja niezgodna art. z 42 ust. 2 w związku z art. 31 ust. 3 Konstytucji RP

\footnotetext{
${ }^{58}$ D. ŚwIECKI, Komentarz do art. 73 k.p.k., LEX/el. 2018, teza 2.

${ }^{59}$ Wyrok Trybunału Konstytucyjnego z dnia 11 grudnia 2012 r., sygn. akt K 37/11, LEX nr 1231298.
} 
i doprowadziło do jego nowelizacji w 2013 r. ${ }^{60}$ i dodania wzmianki, że zastrzeżenie obecności przez zatrzymującego może mieć miejsce „w wyjątkowych wypadkach, uzasadnionych szczególnymi okolicznościami" bez doprecyzowania jednak natury tych ostatnich. Zastosowanie jednakże podwójnej kwantyfikacji (,wyjątkowe wypadki” oraz „szczególne okoliczności”) zdaje się przesądzać o niedopuszczalności nadużywania tego uprawnienia, jako rozwiązania godzącego w prawo do obrony osoby podejrzanej.

Autor konkluduje, iż ,przepisy Kodeksu postępowania karnego” „nie gwarantują [...] należytej ochrony tajemnicy adwokackiej” (s. 47), a przecież wystarczy tylko prześledzić ewolucję rozwiązań tam zawartych, by uznać, że ustawodawca niemal z każdą nowelizacją art. 180 k.p.k. ochronę tę wzmacnia. Przejawem tej tendencji jest nie tylko wyodrębnienie $\mathrm{z}$ art. 180 § 1 k.p.k. i przeniesienie do jego § 2 tych tajemnic, które uznaje się za „ważniejsze”, lecz także przyznanie wyłącznej kompetencji do ich uchylenia sądowi, który na etapie postępowania przygotowawczego może takiego zwolnienia dokonać wyłącznie ,na wniosek prokuratora”. To ostatnie zastrzeżenie wyraźnie ogranicza krąg podmiotów uprawnionych według art. 167 k.p.k. do podjęcia inicjatywy dowodowej, mogącej doprowadzić do naruszenia tajemnicy adwokackiej (lub innej zawodowej). Ustawodawca uznał najwyraźniej, że na tym etapie postępowania karnego tylko prokurator będzie w stanie dokonać wstępnej oceny obu warunków z art. 180 § 2 k.p.k.. I choć ograniczenie to odbywa się kosztem stron procesowych, to przeciwdziała inflacji niezasadnych i pochopnych wniosków dowodowych, mogących skutkować zbędnym ujawnieniem informacji immunizowanych przez tajemnicę adwokacką. Jak inaczej ocenić poddanie postanowienia $\mathrm{w}$ przedmiocie przesłuchania lub zwolnienia $\mathrm{z}$ tajemnicy adwokackiej kontroli instancyjnej (art. 180 § 2 zd. 3 k.p.k.) oraz obwarowanie odnośnej decyzji koniecznością stwierdzenia, że przesłuchanie co do faktów objętych tą tajemnicą musi być „niezbędne dla dobra wymiaru sprawiedliwości, a okoliczność [ta - P.K.S.] nie może być ustalona na podstawie innego dowodu"? Wprawdzie przesłanka „dobra wymiaru sprawiedliwości”, ${ }^{, 1}$ rzeczywiście nie grzeszy przesadną dokładnością (s. 37), a w doktrynie podejmowane były próby jej doprecyzo-

${ }^{60}$ Art. 1 pkt 2 ustawy z dnia 27 września 2013 r. o zmianie ustawy - Kodeks postępowania karnego, Dz. U. poz. 1282.

${ }_{61}$ Trzeba tu zaznaczyć, że już pod rządami poprzedniego Kodeksu postępowania karnego w praktyce wymiaru sprawiedliwości podejmowano próby ograniczenia dostępu do faktów objętych tajemnicą adwokacką. I tak, Sąd Najwyższy w uchwale z dnia 16 czerwca 1994 r. [sygn. akt I KZP 5/94, „Palestra” 7-8 (1994), s. 194-208], opowiedział się za możliwością zwolnienia z niej tylko, gdy ,jest to n i e o d z o w n e dla zapewnienia prawidłowego wyrokowania w sprawie", choć takiego warunku ówcześnie obowiązujący art. 163 w żaden sposób nie wyrażał. 
wania $^{62}$, to jednak od czasu uchwalenia omawianego tu przepisu jakoś nie widać w praktyce wymiaru sprawiedliwości nadmiernej skłonności do nadużywania dowodu z zeznań depozytariuszy tajemnicy adwokackiej z powołaniem się na ów niejasny warunek. Sam jestem zresztą przykładem na całkiem sprawne działanie systemu kontroli sądowej, kiedy to swego czasu - oponując przed ujawnieniem okoliczności objętych tajemnicą radcowską na wczesnym etapie śledztwa - wskazałem, że sięgnięcie przez prokuratora po moje zeznanie jest „pójściem na dowodowe skróty", a rozpoznający wniosek o moje zwolnienie sąd rzeszowski w pełni to zapatrywanie podzielił, wytykając śledczym niezrozumienie subsydiarnego charakteru dowodu wymienionego w art. 180 § 2 k.p.k.

Problemem nie jest więc - jak się wydaje - „brak należytych gwarancji procesowych" dla tajemnicy adwokackiej, lecz to, że na gruncie postępowania karnego zyskuje rację bytu koncepcja rozdzielenia tej tajemnicy na tajemnicę adwokacką nieobrończą i tajemnicę adwokacką obrończą. Trzeba to wyraźnie zaznaczyć, że rozwiązania kodeksowe zawsze będą oceniane jako „niewystarczające”, jeśli omawiać się je będzie z pozycji zwolennika bezwzględnego i niepodzielnego charakteru tajemnicy adwokackiej. Ci ostatni nie dopuszczają bowiem jakiegokolwiek „ważenia” lub „dzielenia” tajemnicy, uznając niejako ex definitione niedopuszczalność jakiejkolwiek ingerencji. Takie podejście utrudnia znacznie możliwość porozumienia i konstruktywnego dyskursu. Poruszone tu kwestie niemal zupełnie umknęły Autorowi, co rodzi pytanie o sens pisania tak niepogłębionego teksu, jak ten opublikowany, nawet jeżeli zastrzega On na wstępie swego opracowania, że jego przedmiotem będą jedynie „zagadnienia wybrane”?

\section{BIBLIOGRAFIA}

ŹRÓDŁA PRAWA

Ustawa z dnia 26 maja 1982 r. Prawo o adwokaturze, Dz. U. z 2018 r., poz. 1184 z późn. zm. Ustawa z dnia 6 lipca 1982 r. o radcach prawnych, Dz. U. z 2017 r., poz. 1870 z późn. zm. Ustawa z dnia 14 lutego 1991 r. Prawo o notariacie, Dz. U. z 2017 r., poz. 2291 z późn. zm. Konstytucja Rzeczypospolitej Polskiej z dnia 2 kwietnia 1997 r., Dz. U. Nr 78, poz. 483 z późn. zm.

\footnotetext{
${ }^{62}$ Sam proponowałem uzupełnienie tej przesłanki warunkiem „niesprzeczności z szczególnie ważnym interesem prywatnym niesprzecznym z celami wymiaru sprawiedliwości” - por. SowiŃSKI, Prawo świadka, s. 217-218. Postulatu tego nie podzielił jednak T. Grzegorczyk wskazując, że rozwiązanie obecnie funkcjonujące było przedmiotem kontroli TK (wyrok z dnia 22 listopada 2004 r., sygn. akt SK 64/03, OTK-A 2004, nr 10, poz. 107), który nie dopatrzył się sprzeczności z art. 49 i art. 51 Konstytucji RP, stąd też zbędne jest wprowadzanie doń „dodatkowych klauzul” (TENŻE, Kodeks, s. 626).
} 
Ustawa z dnia 22 maja 1997 r. o zmianie ustawy - Prawo o adwokaturze, ustawy o radcach prawnych oraz niektórych innych ustaw, Dz. U. Nr 75, poz. 471 z późn. zm.

Ustawa z dnia 6 czerwca 1997 r. Kodeks postępowania karnego, Dz. U. z 2018 r., poz. 1987 z późn. zm.

Ustawa z dnia 21 sierpnia 1997 r. Prawo o ustroju sądów wojskowych, Dz. U. z 2018 r., poz. 1921.

Ustawa $z$ dnia 16 listopada 2000 r. o przeciwdziałaniu praniu pieniędzy oraz finansowaniu terroryzmu, Dz. U. z 2003 r. Nr 153, poz. 1505 z późn. zm.

Ustawa z dnia 24 sierpnia 2001 r. Kodeks postępowania w sprawach o wykroczenia, Dz. U. z 2018 r., poz. 475 z późn. zm.

Ustawa z dnia 5 marca 2004 r. o zmianie ustawy o przeciwdziałaniu wprowadzaniu do obrotu finansowego wartości majątkowych pochodzących z nielegalnych lub nieujawnionych źródeł oraz o przeciwdziałaniu finansowaniu terroryzmu oraz o zmianie niektórych ustaw, Dz. U. Nr 62, poz. 577.

Ustawa z dnia 2 grudnia 2009 r. o izbach lekarskich, Dz. U. z 2018 r., poz. 168 z późn. zm.

Ustawa z dnia 27 września 2013 r. o zmianie ustawy - Kodeks postępowania karnego oraz niektórych innych ustaw, Dz. U. poz. 1247).

Ustawa z dnia 28 stycznia 2016 r. Prawo o prokuraturze, Dz. U. z 2017 r., poz. 1767 z późn. zm.

\section{ORZECZNICTWO}

Uchwała Sądu Najwyższego z dnia 16 czerwca 1994 r., sygn. akt I KZP 5/94, OSNKW 7-8 (1994), poz. 41.

Wyrok Trybunału Konstytucyjnego z dnia 22 listopada 2004 r., sygn. akt SK 64/03, OTK-A 2004, nr 10, poz. 107.

Postanowienie Sądu Apelacyjnego w Katowicach z dnia 5 sierpnia 2015 r., sygn. akt II AKz 443/15, Biuletyn OSA w Katowicach 3 (2015), s. 10-11.

Uchwała Sądu Najwyższego z dnia 16 czerwca 1994 r., sygn. akt I KZP 5/94, Palestra 7-8 (1994), s. $194-208$.

Wyrok Trybunału Konstytucyjnego z dnia 11 grudnia 2012 r., sygn. akt K 37/11, LEX nr 1231298. Wyrok Trybunału Konstytucyjnego z dnia 30 lipca 2014 r., sygn. akt K 23/11, LEX nr 1491305.

Wyrok Sądu Najwyższego z dnia 1 grudnia 2016 r., sygn. akt SDI 65/16, LEX nr 2182292.

INNE

Zbiór Zasad Etyki Adwokackiej i Godności Zawodu (Kodeks Etyki Adwokackiej) uchwalony przez NRA w dniu 10 października 1998 r. (2/XVIII/98) i stanowiący załącznik do obwieszczenia Prezydium NRA z dnia 27 lutego 2018 r. w sprawie ogłoszenia jego tekstu jednolitego.

Uchwała Prezydium NRA z dnia 7 listopada 1968 r., [w:] http://bazhum.muzhp.pl/media//files/Pa lestra/Palestra-r1969-t13-n1(133)/Palestra-r1969-t13-n1(133)-s106-111/Palestra-r1969-t13-n1(133)-s 106-111.pdf [dostęp: 5.11.2018].

\section{LITERATURA}

CIEŚLAK Marian: Zagadnienia dowodowe w procesie karnym, t. I, Warszawa: Wydawnictwo Prawnicze 1955.

CIEŚLAK Marian: Tajemnica adwokacka w procesie karnym. Glosa do wyroku SN z 12 listopada 1964 r. (II KK 1018/61), Państwo i Prawo 3 (1966), s. 588-592. 
DuDKA Katarzyna: Kontrola korespondencji i podsłuch w polskim procesie karnym, Lublin: Wydawnictwo UMCS 1998.

EICHSTAEDT Krzysztof: Komentarz do art. 237 k.p.k., LEX/el. 2018.

GABERLE Andrzej: Glosa do uchwały siedmiu sędziów SN z 16 czerwca 1994 r., I KZP 5/94 (ochrona tajemnicy adwokackiej w świetle art. 1963 k.p.k.), Państwo i Prawo 4 (1995), s. 106-111.

GRUSZECKA Dagmara: Komentarz do art. 178, [w:] Kodeks postępowania karnego. Komentarz, red. J. Skorupka, Warszawa: Wydawnictwo C.H. Beck 2015, s. 412-414.

GRZEGORCZYK Tomasz: Kodeks postępowania karnego. Komentarz do art. 1-467, t. I, Warszawa: Wolters Kluwer 2014.

KŁAK Czesław P.: Ochrona tajemnicy notarialnej w polskim procesie karnym, Prokuratura i Prawo 1 (2013), s. 29-47.

KruK Ewa: Obowiązek zachowania tajemnicy adwokackiej jako okoliczność uzasadniająca odmowę zeznań w trybie art. 180 § 1 k.p.k., Studia Iuridica Lublinensia 4 (2017), s. 25-41.

KUNICKA-MiCHALSKA Barbara: Ochrona tajemnicy zawodowej w polskim prawie karnym, Warszawa: Wydawnictwo Prawnicze 1972.

KUROWSKI Michał: Komentarz do art. 178 k.p.k., LEX/el. 2018.

KRZEMIŃSKI Zdzisław: Prawo o adwokaturze. Komentarz, Warszawa: Wydawnictwo C.H. Beck 1998.

KRZEMIŃSKI Zdzisław: SN: tajemnica adwokacka, Monitor Prawniczy 10 (1994), s. 302-305.

KRZEMIŃSKI Zdzisław: Wystąpienie przed SN na posiedzeniu w dniu 16 czerwca 1994 r. poprzedzającym wydanie uchwały 7 sędziów SN, Palestra 9-10 (1994), s. 66-70.

KwIATKOwSKI Zbigniew: Zakazy dowodowe w procesie karnym, Katowice: Wydawnictwo Uniwersytetu Śląskiego 2001.

KwIATKOwSKI Zbigniew: Zakazy dowodowe w procesie karnym, Kraków: Zakamycze 2005.

ŁOJEWSKI Kazimierz: Instytucja odmowy zeznań w polskim procesie karnym, Warszawa: Wydawnictwo Prawnicze 1970.

MAChNikowsKA Anna: Tajemnica zawodowa, [w:] Granice wolności wypowiedzi przedstawicieli zawodów prawniczych, red. A. Biłgorajski, LEX/el. 2015.

MĄDRECKA Emilia: W kwestii kolizji art. 180 § 2 kodeksu postępowania karnego i art. 6 Prawa o adwokaturze, Nowa Kodyfikacja Prawa Karnego 28 (2012), s. 147-160.

Musialik Gabriela: Dopuszczalność stosowania podsłuchu telekomunikacyjnego w stosunku do osób zobowiązanych do zachowania tajemnicy zawodowej na gruncie Kodeksu postępowania karnego z 1997 roku, Palestra 11-12 (1998), s. 86-95.

PAwELEC Kazimierz J.: Tajemnica zawodowa notariusza w znowelizowanym Kodeksie postępowania karnego. Zagadnienia podstawowe, Rejent 9 (2015), s. 88-100.

RogALSKI Maciej: Podsłuch procesowy i pozaprocesowy, mps złożony do druku, Warszawa: Wolters Kluwer.

RUSINEK Michał: Tajemnica zawodowa i jej ochrona w polskim procesie karnym, Kraków: Wolters Kluwer 2007.

SKręTOwiCZ Edward, Kruk Ewa, O tajemnicy adwokackiej w procesie karnym, Annales UMCS 43 (1996), s. 129-136.

SMARZEWSKI Marek, BANACH Małgorzata: Ochrona tajemnicy w procesie karnym w związku z czynnościami przesłuchania i przeszukania, Palestra 3 (2017), s. 75-87.

ŚLIWIŃSKI Stanisław: Proces karny. Zasady ogólne, Warszawa: Gebethner i Wolff 1948.

SowIŃSKi Piotr K.: Prawo świadka do odmowy zeznań w procesie karnym, Warszawa: Wydawnictwo C.H. Beck 2004. 
SowIŃSKI Piotr K.: Uprawnienia składające się na prawo oskarżonego do obrony. Uwagi na tle czynności organów procesowych oraz oskarżonego, Rzeszów: Wydawnictwo Uniwersytetu Rzeszowskiego 2012.

STEINBORN Sławomir: Komentarz do art. 237 k.p.k., LEX/el. 2016.

ŚwIECKI Dariusz: Komentarz do art. 73 k.p.k., LEX/el. 2018.

TYlmAn Janusz, GRZEGORCZYK Tomasz: Polskie postępowanie karne, Warszawa: Wolters Kluwer 2011.

\author{
JESZCZE O TAJEMNICY ADWOKACKIEJ \\ Z PERSPEKTYWY PRZEPISÓW ART. 178 PKT 1 ORAZ ART. 180 § 2 K.P.K. \\ UWAGI POLEMICZNE
}

Streszczenie

W tekście przedstawiono problematykę dotyczącą ochrony tajemnicy adwokackiej i obrończej w procesie karnym. Wskazano na zakres przedmiotowy obu tych tajemnic oraz środki służące ich ochronie. Tekst zawiera krytyczne uwagi w stosunku do artykułu P. Krzyżanowskiego „Zakres ochrony tajemnicy adwokackiej w postępowaniu karnym - zagadnienia wybrane".

Słowa kluczowe: adwokat; tajemnica obrończa; tajemnica zawodowa; zwolnienie z tajemnicy zawodowej

\title{
THE LEGAL PRIVILEGE IN THE CONTEXT OF THE PROVISIONS OF ARTICLE 178 § 1 AND 180 § 2 OF THE CRIMINAL PROCEDURE CODE. POLEMICAL REMARKS
}

\section{S u m m a r y}

The issue concerning the protection of attorney-client privilege and legal privilege was presented in this article. The scope of these privileges and the measures to their protection were indicated. This polemic contains some criticisms regarding P. Krzyżanowski's article „The Scope of the Protection of Legal Privilege In Criminal Proceeding - Selected Issues".

Key words: counsellor; legal privilege; professional secrecy; professional secrecy release 